\title{
Cleptobiosis in Social Insects
}

\author{
Michael D. Breed, Chelsea Cook, and Michelle O. Krasnec \\ Department of Ecology and Evolutionary Biology, The University of Colorado, Boulder, \\ CO 80309-0334, USA \\ Correspondence should be addressed to Michael D. Breed, michael.breed@colorado.edu
}

Received 12 October 2011; Accepted 18 December 2011

Academic Editor: Jean Paul Lachaud

Copyright ( $) 2012$ Michael D. Breed et al. This is an open access article distributed under the Creative Commons Attribution License, which permits unrestricted use, distribution, and reproduction in any medium, provided the original work is properly cited.

\begin{abstract}
In this review of cleptobiosis, we not only focus on social insects, but also consider broader issues and concepts relating to the theft of food among animals. Cleptobiosis occurs when members of a species steal food, or sometimes nesting materials or other items of value, either from members of the same or a different species. This simple definition is not universally used, and there is some terminological confusion among cleptobiosis, cleptoparasitism, brood parasitism, and inquilinism. We first discuss the definitions of these terms and the confusion that arises from varying usage of the words. We consider that cleptobiosis usually is derived evolutionarily from established foraging behaviors. Cleptobionts can succeed by deception or by force, and we review the literature on cleptobiosis by deception or force in social insects. We focus on the best known examples of cleptobiosis, the ectatommine ant Ectatomma ruidum, the harvester ant Messor capitatus, and the stingless bee Lestrimellita limão. Cleptobiosis is facilitated either by deception or physical force, and we discuss both mechanisms. Part of this discussion is an analysis of the ecological implications (competition by interference) and the evolutionary effects of cleptobiosis. We conclude with a comment on how cleptobiosis can increase the risk of disease or parasite spread among colonies of social insects.
\end{abstract}

\section{Introduction}

For animals, foraging is often time consuming, risky and may not result in the discovery of food or other resources. A commonly observed alternative to searching for resources that may be dispersed in the environment is to take, either by force or deception, the resource from another animal. This theft of food or other resources from foragers or from larder caches is common enough to merit considerable interest in behavioral ecology. Many social insects act as thieves, and the focus of this paper is food theft that in some way involves a social insect species, but we also consider theft of other items, such as nesting material. We also consider how theft among social insects fits into the larger evolutionary picture of resource theft in animals. Social insects can be either the victim or the villain in food thefts. Some social insects frequently victimize other social insects, and these thieves may be members of the same species or of a different species. Social insects can also be victimized by commensals that are able to plug into social feeding mechanisms that normally direct food among colony members.
From this point forward, we use the term cleptobiosis to describe food theft, or theft of other items of value such as nesting material, by one animal from another. The evolutionary roots of cleptobiosis are simple; finding food and subduing prey items is key to animal survival, and cleptobiosis provides, for some species, an alternative to foraging costs in terms of time, energy, and exposure to the possible risk of the forager becoming, itself, prey. Most cleptobionts facultatively engage in theft, when profitable opportunities appear, but obligate cleptobiosis has evolved in at least one genus of stingless bee and in inquilines residing within social insect colonies. While the subject of this paper is cleptobiotic relationships involving social insects, the evolutionary principles apply broadly across many types of animals.

\section{What Is Cleptobiosis?}

This is an easy question with an unfortunately complicated answer. At the outset we gave a simple definition; in more formal terms we consider cleptobiosis to be "an ecological 
relationship in which members of one species, as of ants, steal food from another" (http://universalium.academic.ru/ 93503/cleptobiosis), but we would add that the stolen items may also include nesting materials or other items of value. The term can also be spelled kleptobiosis, and, in studies of animals outside the social insects, kleptoparasitism (cleptoparasitism) is often used synonymously with cleptobiosis. However, serious confusion can arise from the different ways in which these terms have been used in the literature on insects and the literature on vertebrates, and in the remainder of this section we discuss how this terminology has been applied by investigators studying different types of organisms. Iyengar [1] presents a general review of cleptobiosis in animals.

In insect studies, cleptobiosis refers to food theft (or other valuable materials), and cleptoparasitism refers to brood parasitism (Table 1). Alternatively, the term cuckoo or cuckooism is used to describe brood parasites among birds and mammals, as well as bees. Cuckoo bees are brood parasites (strictly speaking, this is family Apidae, subfamily Nomadinae, but also refers to other bees with similar lifestyles) and are often termed cleptoparasites. These bee species lay their eggs in the nests of other bee species, rather than stealing food. Their young are then reared by adults of the host species [2]. Brood parasitism of this sort is also characteristic of birds such as cuckoos (family Cuculidae) [3] and cowbirds (Icteridae). Unfortunately, the term cleptoparasitism (or kleptoparasitism) is also frequently used to describe food theft in bird and mammals [4]. Adding to the terminological confusion is the occasional use of lestobiosis to refer to more furtive (as opposed to forcible) forms of cleptobiosis.

We view cleptobiosis as theft of food or other valuable items and prefer other terms to describe brood parasitism. In some cases, as in gulls stealing from one another on a beach, the theft is direct interference with immediate consumption. In other cases, such as honeybees robbing honey from a hive, the target is stored food in a nest or cache. To avoid confusion, species that lay eggs in the nests of others (either conspecific or heterospecific) are probably better termed cuckoos or brood parasites, rather than cleptoparasites. This paper focuses specifically on cleptobiosis, defined as food thievery, in social insects.

Adding to the confusion, Crespi and Abbot [10] call thrips that steal galls induced by other thrip species cleptoparasites. Nest usurpation is also known in honeybees and in a broader context is similar to territorial contests in birds and mammals, in which an individual may lose a nesting site. We do not include nest usurpation in our review.

Theft of brood for the purpose of employing the stolen individual's efforts in support of the thief is dulosis (in the older literature this is called slave-making, but the preferred terms is now dulosis). Dulosis is common in ants but is only incidentally observed in other types of animals. Inquilinism is social parasitism in which a reproductive enters a host colony, lays eggs, and relies on the host colony to rear its offspring. Unlike brood parasitism, the inquiline remains within the nest and typically its brood does not outnumber the host's brood. Inquilines are typically evolutionarily close to their hosts, as with ants living within the colonies of another ant species. Inquilines may, of course, take food from the host colony, potentially making this behavior a kind of cleptobiosis. Consumption of brood, as by corvids (family Corvidae: ravens, crows, magpies, and jays), which target eggs and nestlings of smaller birds [16], is predation rather than cleptobiosis.

Before moving on to our consideration of cleptobiosis, one other type of interspecific interaction that should be discussed is "guests" in social insect colonies. This type of symbiosis is related in some ways to cleptobiosis. Ant and termite colonies, in particular, often have guests, which are termed myrmecophiles and termitophiles, respectively. Guests living with ants include other ant species, beetles, flies, and Collembola. Larvae of lycaenid butterfly species display a variety of mechanisms-chemical, morphological, and behavioral-to induce care from ants $[17,18]$. Like furtive cleptobionts, many of these symbionts "gain the keys to the kingdom" by mimicking the chemical recognition signatures of the host colony, a mechanism that we discuss in more detail below.

\section{Nonsocial Insect Cleptobionts}

Social insects are not the only members of cleptobiotic associations. Many animal species use cleptobiosis to exploit social information. This makes their search for food more efficient $[19,20]$. By observing other animals' foraging activities, an animal can take advantage of information that took another individual's time and energy to discover. Birds in a flock may assemble, for example, to obtain social information about food [21]. In some cases such information theft leads to direct stealing of food. Heron gulls voraciously attempt to steal each other's food discoveries [7]. Spiders steal food from each other in a similar manner $[22,23]$. Interspecific theft of food items is common among carnivorous mammals, with thefts by hyenas in which wild dogs are victimized having been particularly well studied [24], although no mammalian or avian species makes their living solely by stealing food items from other species.

Taking this logic a step further, targeting cached food can be a highly efficient strategy [25]. Scatter caching is a form of food storage in which single food items are placed in caches within an animal's home range. Sometimes, as in jays or squirrels, this can result in a high number of caches of food to be retrieved in a later season. Scatter caching is also subject to pilferage, but scatter caching animals typically do not defend individual caches. Ravens, for example, seek out each other's food caches [25]. Raven defenses against cache pilferage largely rely on clever storage, rather than aggressive defense. However, when a mountain lion caches a deer carcass, it may then defend its food. In scatter caching, cache locations are associated with where prey was killed, rather than a central nest or den.

Among mammals and birds, caching seems responsive to immediate evolutionary pressures. Tree squirrels exemplify evolutionary flexibility in caching strategies, as some species are scatter cachers (e.g., the Eastern fox squirrel, Sciurus 
TABLE 1: Terminology for food theft, brood theft, brood parasitism, and related phenomena. The term "cleptoparasite" has been used with such diverse meanings that it is probably best dropped from the lexicon for this area.

\begin{tabular}{|c|c|c|}
\hline Term & Function & Example \\
\hline Cleptobiosis & $\begin{array}{l}\text { Theft of food or another item of value from } \\
\text { another animal }\end{array}$ & $\begin{array}{l}\text { Gulls [5], honeybees [6], Ectatomma ants } \\
{[7,8] \text {, bowerbirds (mating display }} \\
\text { materials) [9] }\end{array}$ \\
\hline Lestobiosis & Cleptobiosis by furtive or deceptive means & Ectatomma ants $[7,8]$ \\
\hline Nest usurpation & $\begin{array}{l}\text { Theft of a nest structure, perhaps including } \\
\text { brood or food cached within the nest }\end{array}$ & Honeybees [6], thrips [10] \\
\hline Brood parasitism & $\begin{array}{l}\text { Laying eggs in the nest of another animal, to } \\
\text { be reared by that animal, functionally, this is } \\
\text { theft of brood rearing }\end{array}$ & Cuckoos (birds) [3], cuckoo bees [2] \\
\hline Dulosis & Theft of brood to rear as workers & "Slave-making" ants [11] \\
\hline Inquilinism & $\begin{array}{l}\text { Living within a social group as a social } \\
\text { parasite, a conspecific or heterospecific } \\
\text { reproductive that exploits the host colony by } \\
\text { laying brood that are cared for by the host } \\
\text { colony }\end{array}$ & $\begin{array}{l}\text { Psithyrus bees in bumblebee (Bombus) } \\
\text { colonies, Dolichovespula arctica and } D . \\
\text { adulterina, (initially inquilines, often } \\
\text { become usurpers) in other Dolichovespula } \\
\text { colonies }[12,13], \text { numerous ant species } \\
\text { within other ant colonies [11] }\end{array}$ \\
\hline $\begin{array}{l}\text { Guests, } \\
\text { myrmecophiles, and } \\
\text { termitophiles }\end{array}$ & $\begin{array}{l}\text { Live within a social insect colony, often } \\
\text { adopting chemical recognition signature of } \\
\text { host colony, may consume resources but do } \\
\text { not represent a lethal drain on colony } \\
\text { resources }\end{array}$ & $\begin{array}{l}\text { Many species representing many insect } \\
\text { orders, as well as noninsects. Specific } \\
\text { examples are lycaenid Lepidoptera in ant } \\
\text { colonies }[14,15] \text { and wax moths, Galleria } \\
\text { mellonella, in honeybee colonies [6] }\end{array}$ \\
\hline Parasites & $\begin{array}{l}\text { Live within a social insect colony but } \\
\text { represent a potentially lethal presence }\end{array}$ & Varroa mites in honeybee colonies [6] \\
\hline Brood predation & Eating eggs or brood from within a nest & $\begin{array}{l}\text { Corvids (ravens, crows, magpies) } \\
\text { consuming other bird's eggs, army ants, } \\
\text { many species of which target brood of other } \\
\text { social insects [1] }\end{array}$ \\
\hline
\end{tabular}

niger), and others are larder cachers (e.g., the pine squirrel, Tamiasciurus hudsonicus). The difference between these species may in part reflect differing pressures from cache pilferage.

\section{Larder Caches and the Evolution of Cleptobiosis}

A larder cache is food stored in a central place for future use. Food stored in larder caches is particularly attractive to potential thieves, and many larder caching social insect species, such as harvester ants, most stingless bees, and honeybees, have evolved impressive modes of colony defense. The evolution of larder caching is probably driven by the value of having food in a central place during unfavorable seasons, but the threat of loss of the cache, to animals of the same species or different species, is clearly a countervailing evolutionary force. Larder caching occurs in some ants and social bees, and to a lesser extent in social wasps, and is particularly important in our discussion of cleptobiosis in social insects. The long-term survival of social insect nests containing stored food, sometimes spanning many years, may help to make their colonies particularly susceptible to repeated raids.

For some individuals within a population, taking food from others can become the predominant mode of food collection, but robbing conspecifics is not an evolutionarily stable strategy for all individuals within a population-it is clearly a dead-end if all animals in a population are robbers and none are foraging independently. Heterospecific food theft, on the other hand, can lead to obligate cleptobiotic specialization. An example of an obligate cleptobiont is the stingless bee, Lestrimellita limão $[14,15]$.

Social insect species may be particularly well equipped to engage in cleptobiosis, as the victim and thief share social mechanisms, and thief workers can evolve for specialized foraging roles without conflict with reproduction, which is the province of the queen in the colony [26]. Larder caching social insects are also victimized by birds and mammals. Perhaps most famously the western honeybee, Apis mellifera, is well armed to protect itself against vertebrate cache thieves attempting to access stored honey.

\section{From Foraging to Cleptobiosis}

Cleptobiosis often appears to have arisen from foraging behavior that is redirected to stored foods. Stored food presents some of the same sensory profiles as the food in its original state; honey is both sweet and imbued with floral scents even though it has been concentrated from nectar and is found in honeycombs rather than flowers. Western honeybee, A. mellifera, colonies commonly rob honey from 
other colonies. The western honey bee is a feeding generalist and forages on both floral and nonfloral sources of sugars, such as extrafloral nectaries. The evolutionary switch from foraging on nectar collected at flowers and extrafloral nectaries to foraging on stored honey in other bees' colonies is within the foraging flexibility of honeybees and may not have required any particular adaptations to allow bees to make this switch.

Other social insects, such as the ectatommine ant, Ectatomma ruidum, have made similar shifts, but have mechanisms for evading detection by workers in the colony being robbed. In more extreme cases, cleptobiosis involves specific adaptations for thievery from colonies of other social insects. Members of the stingless bee genus, Lestrimellita, are good examples of this. Lestrimellita species no longer forage on floral sources, instead they have evolved as an obligate robber of other stingless bee species. These examples, $E$. ruidum and L. limão, are discussed in more detail below.

Cleptobiosis can be intraspecific or interspecific. The focus on food collected by the victim, rather than the victim itself, differentiates this behavior from predation. The evolution of cleptobiosis appears to draw from foraging behaviors, but also may involve the evolution of specific mechanisms for overcoming defenses of the victimized colony. Guarding honey bees [27], for example, serve a primary function of preventing cleptobiosis. The number of guards present and the intensity of guarding behavior are responsive to the intensity of pressure from robbing bees from other colonies [28]. This is an interesting example of intraspecific coevolution, in which robbing behavior yields a fitness reward for their colony, but pressure from robbers results in the evolution of heightened defensive behavior [28].

A shift in foraging preferences is a reasonable hypothesis for the initial evolution of cleptobiosis. But how does obligate cleptobiosis evolve? The most likely evolutionary scenario seems to be first facultative cleptobiosis on other species, followed by the evolutionary loss of noncleptobiotic foraging preferences. Hölldobler and Wilson [11, Chapter 12], give a detailed discussion of how predation and territoriality might lead to dulosis and inquilinism. Nearly all of our examples of species exhibiting cleptobiosis are facultative cleptobionts. For individuals of these species, the ability to be a cleptobiont adds foraging opportunities and often allows these animals to take advantage of public information concerning food availability. Obligate cleptobiosis enables the evolutionary loss of specializations, such as pollen carrying structures, and the evolution of special abilities for overcoming nest entrance guards; both of these evolutionary outcomes are seen in the stingless bee genus Lestrimellita. However, obligate cleptobionts are uncommon, suggesting that perhaps this is a narrow niche which can only be filled under fairly conscribed circumstances.

\section{Army Ants and Predation on Social Insect Brood}

Army ants cross the line from cleptobiosis to predation, but they merit mention here because many army ant species are feeding specialists on the brood of other social insect species.
Army ants subdue their prey by force, rather than by deception, but their match in body size, social behavior, and their ability to recruit colony mates to food sources, makes their predatory behavior in some ways homologous to the brood capturing behavior of dulotic ants. The culminative act, predation or capture of labor, surely differs, but the ultimate outcome for the victimized colony is similar. Hölldobler and Wilson [11, Chapter 12] give a more detailed discussion of the possible intertwining of evolutionary pathways between predation and dulosis.

\section{How Do Cleptobionts Succeed?}

There are two basic strategies that cleptobionts can use to enter a target colony: deception and force. Deceptive entry usually involves furtive behavior, sometimes combined with manipulation of the chemical signals involved in nestmate recognition. We discuss these two strategies in more detail in the following two sections.

7.1. Cleptobiosis by Deception: Evading Nestmate Recognition and Guards. In some cases successful cleptobiosis is dependent on exploitation of social mechanisms. One common mechanism is evasion of a species' nestmate recognition system. For a colony to defend itself against potential cleptobionts, workers in the colony must be able to discriminate nestmates from nonnestmates. The presence of a nonnestmate within the colony, or at the colony entrance, is typically detected through differences in surface chemistry between colony residents and nonresidents [6, 2931]. Residents defensively respond to perceived differences, biting and stinging (if a sting is present in the species) the intruders. Often the defenders are specialized guards, which are primed to respond to nonnestmates.

The chemical cues used in nestmate recognition are typically hydrocarbons that are probably coopted from their original role as cuticular waterproofing [32]. In Polistes wasps and in honeybees, nestmate recognition cues are acquired from nesting materials and all individuals in a colony present similar chemical signatures [6]. The mode of cue acquisition varies among ant species, but in at least some ants the postpharyngeal gland serves as a "gestalt" organ for a unifying colonial odor [33]. Potential cleptobionts can evade a chemical nestmate recognition system either by mimicking the chemical signature of the target colony or by not presenting a chemical signature of their own (figuratively speaking, they are a blank slate). The threat of cleptobiosis and social parasitism may be driving forces in the evolution of efficient nestmate recognition systems.

In E. ruidum, a neotropical ectatommine ant, cleptobiosis is common among colonies [7, 8, 34-36]. Ectatomma ruidum colonies are small, with typically fewer than 100 workers, and are abundant in many lowland dry, moist, and wet habitats. Ectatomma ruidum forages on small arthropods, seeds, and nectar. Where they occur they are abundant, with a mean distance of 1 to 2 meters between neighboring colonies. Foragers will repeatedly attempt to gain entrance into neighboring nests. These repeated attempts cooccur 
with a reduction of concentration of cuticular hydrocarbons and with a convergence of cuticular hydrocarbons between the thief ant and the target colony. After repeated attempts, thieves can gain entry into target colonies without resistance and position themselves to receive food from foragers returning to the colony. They then depart and carry the food to their own colony. Ironically, colonies of equal strength, in terms of the number of workers, tend to equally rob each other, with no net effect on food flow into the colonies. Small colonies are at a distinct disadvantage and tend to lose considerably more food than they gain [37]. This is a clear example of cleptobiosis by deception.

7.2. Cleptobiosis by Force. The stingless bee, L. limão, is an obligate cleptoparasite of other stingless bees, and sometimes has been observed robbing honeybee colonies [38]. The highly sclerotized workers of $L$. limão [14] have a strong lemon odor due to the presence of citral. A common victim of L. limão is Tetragonisca angustula, a very common bee in the neotropics. One kind of guard in T. angustula hovers around the nest entrance [39-41]; hundreds of these hovering guards are present at any given time, making the presence of a nest of this species easily observable. When a $L$. limão worker enters the defensive perimeter of a T. angustula colony, the guards are alerted by the flight pattern, color, and odor of the intruder. Tetragonisca angustula guards cannot outfight the larger, more heavily armored L. limão workers, but can successfully disable L. limão by biting onto a leg or wing, once the hold on the intruder is secured, the $L$. limão worker ability to fly is compromised by the weight and imbalance created by the attached T. angustula worker [42]. If a T. angustula colony is effective against the first arriving $L$. limão, then the attack is not serious. If $L$. limão workers evade detection, then they recruit massive numbers of additional attackers, and the T. angustula colony will be overrun by cleptobionts. Lestrimellita may steal plant resins used in nest construction, as well as food [43].

In the western honey bee, A. mellifera, rich food resources, in the forms of pollen and honey, are stored within the nest. This food supports survival of the colony through cold temperate winters and provides reserves that allow rapid colony buildup in the spring and investment in reproduction (swarms and drones) early in the growing season. The presence of massive nutritional reserves provides a tempting target, and honey bee colonies can target each other for theft of food, particularly honey. This behavior fits well within our definition of cleptobiosis. Guard honeybees use chemical cues to discriminate nestmates from nonnestmates and act to exclude robbers from the nest [27, 44]. Weaker honeybee colonies are more susceptible to being robbed, and if guards are unable to exclude the first few robbers, massive recruitment of additional robbers may result in the targeted colony being overwhelmed [28].

Ectatomma ants, which were described above as deceptive cleptobionts, forcibly gain food from the ant Pheidole radoszkowskii [8]. Ectatomma ants have also been observed as victims of interspecific cleptobiosis. Ectatomma tuberculatum workers collect nectar and carry droplets externally, between their mandibles, making them a potential target for cleptobiosis. Richard et al. [45] observed Crematogaster limata parabiotica workers robbing nectar from E. tuberculatum workers. Crematogaster workers were able to enter E. tuberculatum nests, but food theft was targeted at E. tuberculatum workers that were returning to their nest.

Espadaler et al. [46] observed ant, Messor barbarus and Aphaenogaster senilis, workers robbing Euphorbiaceae seeds from workers of other species, particularly Tapinoma erraticum (referred to as T. nigerrimum). Ants in the genus Messor are seed harvesters, so it is easy to see cleptobiosis of seeds by Messor workers as a fairly simple shift in foraging strategy. Aphaenogaster species show a wider range of food preferences, but A. senilis workers collect Euphorbiaceae seeds in the Mediterranean habitat in which this study was conducted. Messor capitatus workers engage in a variety of interference tactics that affect foraging by congeners, including cleptobiosis of seeds $[47,48]$. Similarly, honey ant, Myrmecocystus mimicus, workers rob insect prey items from harvester ant, Pogonomyrmex, workers returning to their colonies [49].

Additional examples expand the range of species that can engage in forcible cleptobiosis. LaPierre et al. [50] observed Polybioides tabida F. (Ropalidiini) wasps robbing workers of the ant, Tetraponera aethiops. The wasp, Charterginus $s p$., (Epiponini) robs food normally collected by mutualistic ants on acacias. Corbara and Dejean [51] reported theft of paper nest material from ants by the social wasp Agelaia fulvofasciata. In sum, cleptobiosis is exhibited by ants, bees, and wasps, giving support to the hypothesis that cleptobiosis is easily derived from preexisting features such foraging preferences, territorial behavior, and social mechanisms such as kin recognition.

\section{Cleptobiosis and the Risk of Disease Spread}

Cleptobionts, by coming into close contact with conspecifics, put themselves at risk for exposure to any disease their victim might carry. This becomes particularly important if the victim's weakness from disease makes them an easier target for cleptobiosis. Increased risk of disease transmission through cleptobiosis is best known in honeybees, A. mellifera [52]. Colonies weakened by the bacterial disease, American Foul Brood, Paenibacillus larvae, the intestinal parasite, Nosema, or by Varroa mites are much less well able than healthy colonies to defend themselves against robber bees from other colonies [52].

\section{Discussion}

Food theft-cleptobiosis-is an important form of intercolonial interaction in social insects. In this paper we have defined cleptobiosis and discussed the difference between cleptobiosis and other types of interactions among social insect colonies, such as dulosis. We also suggest that the term "cleptoparasitism" has been used in so many different ways that it has lost its usefulness and should be avoided. We point out that brood parasitism, inquilinism, and "guests" 
in social insect colonies all may involve mechanisms similar to cleptobiosis. Cleptobionts may be divided into deceptive and forceful types. Deceptive cleptobionts bear considerable resemblance to "guests" in the manner in which they gain entrance to target colonies.

The ecological implications of cleptobiosis are clear, and the reader should refer to Hölldobler's [49] discussion of the significance of cleptobiotic ants in interference competition among ant colonies. Cleptobiosis can function as an extension of territorial behavior of a colony, weakening nearby colonies. In larder hoarding social insects, such as the honeybee, attacks on stored food can contribute to colony decline and failure.

The evolutionary effects of cleptobiosis are largely seen in well-developed nestmate recognition systems. The ability to discriminate and exclude nonnestmates can help to prevent entry by cleptobionts, brood parasites, and inquilines, as well as functioning in territorial interactions. Understanding the relative importance of these factors in shaping nestmate recognition systems remains an important goal for future research.

\section{References}

[1] E. V. Iyengar, "Kleptoparasitic interactions throughout the animal kingdom and a re-evaluation, based on participant mobility, of the conditions promoting the evolution of kleptoparasitism," The Biological Journal of the Linnean Society, vol. 93, no. 4, pp. 745-762, 2008.

[2] S. Cardinal, J. Straka, and B. N. Danforth, "Comprehensive phylogeny of apid bees reveals the evolutionary origins and antiquity of cleptoparasitism," Proceedings of the National Academy of Sciences of the United States of America, vol. 107, no. 37, pp. 16207-16211, 2010.

[3] R. B. Payne, The Cuckoos: Cuculidae, Oxford University Press, Oxford, UK, 2005.

[4] I. M. Hamilton, "Kleptoparasitism and the distribution of unequal competitors," Behavioral Ecology, vol. 13, no. 2, pp. 260-267, 2002.

[5] G. S. Lebaron and F. H. Heppner, "Food theft in the presence of abundant food in herring gulls," The Condor, vol. 87, pp. 430-431, 1985.

[6] M. D. Breed and R. Buchwald, "Cue diversity and social recognition," in Organization of Insect Societies: From Genome to Sociocomplexity, J. Gadau and J. H. Fewell, Eds., pp. 173194, Harvard University Press, Cambridge, Mass, USA, 2008.

[7] M. D. Breed, P. Abel, T. J. Bleuze, and S. E. Denton, "Thievery, home ranges, and nestmate recognition in Ectatomma ruidum," Oecologia, vol. 84, no. 1, pp. 117-121, 1990.

[8] I. Perfecto and J. H. Vandermeer, "Cleptobiosis in the ant Ectatomma ruidum in Nicaragua," Insectes Sociaux, vol. 40, no. 3, pp. 295-299, 1993.

[9] N. R. Doerr, "Does decoration theft lead to an honest relationship between male quality and signal size in great bowerbirds?" Animal Behaviour, vol. 79, no. 3, pp. 747-755, 2010.

[10] B. Crespi and P. Abbot, "The behavioral ecology and evolution of kleptoparasitism in Australian gall thrips," The Florida Entomologist, vol. 82, no. 2, pp. 147-164, 1999.

[11] B. Hölldobler and E. O. Wilson, The Ants, Harvard University Press, Cambridge, Mass, USA, 1990.
[12] R. D. Akre, A. Greene, J. F. MacDonald, P. J. Landolt, and H. G. Davis, Yellowjackets of American North of Mexico, vol. 552 of Agriculture Handbook, U.S. Department of Agriculture, 1980.

[13] L. Dvořák, "Parasitism of Dolichovespula norwegica by $D$. adulterina (Hymenoptera: Vespidae)," Silva Gabreta, vol. 13, no. 1, pp. 65-67, 2007.

[14] S. F. Sakagami, D. W. Roubik, and R. Zucchi, "Ethology of the robber stingless bee, Lestrimelitta limão (Hymenoptera, Apidae)," Sociobiology, vol. 21, no. 2, pp. 237-277, 1993.

[15] D. W. Roubik, "Stingless bee nesting biology," Apidologie, vol. 37, no. 2, pp. 124-143, 2006.

[16] T. E. Martin, "Nest predation among vegetation layers and habitat types: revising the dogmas," The American Naturalist, vol. 141, no. 6, pp. 897-913, 1993.

[17] A. Dejean and G. Beugnon, "Host-ant trail following by myrmecophilous larvae of Liphyrinae (Lepidoptera, Lycaenidae)," Oecologia, vol. 106, no. 1, pp. 57-62, 1996.

[18] N. E. Pierce, M. F. Braby, A. Heath et al., "The ecology and evolution of ant association in the Lycaenidae (Lepidoptera)," Annual Review of Entomology, vol. 47, pp. 733-771, 2002.

[19] C. W. Clark and M. Mangel, "Foraging and flocking strategies: information in an uncertain environment," The American Naturalist, vol. 123, no. 5, pp. 626-641, 1984.

[20] T. J. Valone, "Group foraging, public information, and patch estimation," Oikos, vol. 56, no. 3, pp. 357-363, 1989.

[21] K. A. Schmidt, S. R. X. Dall, and J. A. van Gils, "The ecology of information: an overview on the ecological significance of making informed decisions," Oikos, vol. 119, no. 2, pp. 304316, 2010.

[22] P. Grostal and D. E. Walter, "Kleptoparasites or commensals? Effects of Argyrodes antipodianus (Araneae: Theridiidae) on Nephila plumipes (Araneae: Tetragnathidae)," Oecologia, vol. 111, no. 4, pp. 570-574, 1997.

[23] S. Pekár, "Poor display repertoire, tolerance and kleptobiosis: results of specialization in an ant-eating spider (Araneae, Zodariidae)," Journal of Insect Behavior, vol. 17, no. 4, pp. 555568, 2004.

[24] S. Creel and N. M. Creel, "Limitation of African wild dogs by competition with larger carnivores," Conservation Biology, vol. 10, no. 2, pp. 526-538, 1996.

[25] T. Bugnyar and B. Heinrich, "Pilfering ravens, Corvus corax, adjust their behaviour to social context and identity of competitors," Animal Cognition, vol. 9, no. 4, pp. 369-376, 2006.

[26] A. Lenoir, P. D’Ettorre, and C. Errard, “Chemical ecology and social parasitism in ants," Annual Review of Entomology, vol. 46, pp. 573-599, 2001.

[27] A. J. Moore, M. D. Breed, and M. J. Moor, "The guard honey bee: ontogeny and behavioural variability of workers performing a specialized task," Animal Behaviour, vol. 35, no. 4, pp. 1159-1167, 1987.

[28] M. J. Couvillon, E. J. H. Robinson, B. Atkinson, L. Child, K. R. Dent, and F. L. W. Ratnieks, "En garde: rapid shifts in honeybee, Apis mellifera, guarding behaviour are triggered by onslaught of conspecific intruders," Animal Behaviour, vol. 76, no. 5, pp. 1653-1658, 2008.

[29] M. D. Breed, "Chemical cues in kin recognition: criteria for identification, experimental approaches, and the honey bee as an example," in Pheromone Communication in Social Insects: Ants, Wasps, Bees, and Termites, R. K. Vander Meer, M. D. Breed, M. L. Winston, and K. E. Espelie, Eds., pp. 57-78, Westview Press, Boulder, Colo, USA, 1998.

[30] M. D. Breed, E. Guzmán-Novoa, and G. J. Hunt, "Defensive behavior of honey bees: organization, genetics, and 
comparisons with other bees," Annual Review of Entomology, vol. 49, pp. 271-298, 2004.

[31] J. Kroiss, T. Schmitt, and E. Strohm, "Low level of cuticular hydrocarbons in a parasitoid of a solitary digger wasp and its potential for concealment," Entomological Science, vol. 12, no. 1, pp. 9-16, 2009.

[32] E. B. Edney, Water Balance in Land Arthropods, Springer, New York, NY, USA, 1977.

[33] V. Soroker, C. Vienne, A. Hefetz, and E. Nowbahari, "The postpharyngeal gland as a "Gestalt" organ for nestmate recognition in the ant Cataglyphis niger," Naturwissenschaften, vol. 81, no. 11, pp. 510-513, 1994.

[34] M. D. Breed, T. P. McGlynn, E. M. Stocker, and A. N. Klein, "Thief workers and variation in nestmate recognition behavior in a ponerine ant, Ectatomma ruidum," Insectes Sociaux, vol. 46, no. 4, pp. 327-331, 1999.

[35] J. M. Jeral, M. D. Breed, and B. E. Hibbard, "Thief ants have reduced quantities of cuticular compounds in a ponerine ant, Ectatomma ruidum," Physiological Entomology, vol. 22, no. 3, pp. 207-211, 1997.

[36] J.-C. Lenoir, J.-P. Lachaud, A. Nettel, D. Fresneau, and C. Poteaux, "The role of microgynes in the reproductive strategy of the neotropical ant Ectatomma ruidum," Naturwissenschaften, vol. 98, no. 4, pp. 347-356, 2011.

[37] P. De Carli, J.-P. Lachaud, G. Beugnon, and J. A. LópezMéndez, "Études en milieu naturel du comportement de cleptobiose chez la fourmi néotropicale Ectatomma ruidum," Actes des Colloques Insectes Sociaux, vol. 11, pp. 29-32, 1998.

[38] C. D. Michener, The Comparative Social Behavior of the Bees, Belknap Press of Harvard University Press, Cambridge, Mass, USA, 1974.

[39] D. Wittmann, R. Radtke, J. Zeil, G. Lübke, and W. Francke, "Robber bees (Lestrimelitta limão) and their host chemical and visual cues in nest defense by Trigona (Tetragonisca) angustula (Apidae: Meliponinae)," Journal of Chemical Ecology, vol. 16, no. 2, pp. 631-641, 1990.

[40] R. M. Bowden, M. F. Garry, and M. D. Breed, "Discrimination of con-and heterospecific bees by Trigona (Tetragonisca) angustula guards," Journal of the Kansas Entomological Society, vol. 67, no. 1, pp. 137-139, 1994.

[41] M. H. Kärcher and F. L. W. Ratnieks, "Standing and hovering guards of the stingless bee Tetragonisea angustula complement each other in entrance guarding and intruder recognition," Journal of Apicultural Research, vol. 48, no. 3, pp. 209-214, 2009.

[42] J. S. van Zweden, C. Grüter, S. M. Jones, and F. L. W. Ratnieks, "Hovering guards of the stingless bee Tetragonisca angustula increase colony defensive perimeter as shown by intra-and inter-specific comparisons," Behavioral Ecology and Sociobiology, vol. 65, no. 6, pp. 1277-1282, 2011.

[43] S. F. Sakagami and S. Laroca, "Additional observations on the habits of the cleptobiotic stingless bees, the genus Lestrimelitta Friese (Hymenoptera, Apoidea)," Journal of the Faculty of Science, vol. 15, no. 2, pp. 319-339, 1963.

[44] A. Stabentheiner, H. Kovac, and S. Schmaranzer, "Honeybee nestmate recognition: the thermal behaviour of guards and their examinees," Journal of Experimental Biology, vol. 205, no. 17, pp. 2637-2642, 2002.

[45] F.-J. Richard, A. Dejean, and J.-P. Lachaud, "Sugary food robbing in ants: a case of temporal cleptobiosis," Comptes Rendus Biologies, vol. 327, no. 5, pp. 509-517, 2004.

[46] X. Espadaler, C. Gómez, and D. Suñer, "Seed-robbing between ant species intervenes in the myrmecochory of Euphorbia characias (Euphorbiaceae)," Psyche, vol. 102, no. 1-2, pp. 19-25, 1995.

[47] T. Yamaguchi, "Intraspecific competition through food robbing in the harvester ant, Messor aciculatus (Fr. Smith), and its consequences on colony survival," Insectes Sociaux, vol. 42, no. 1, pp. 89-101, 1995.

[48] D. A. Grasso, A. Mori, M. Giovannotti, and F. Le Moli, "Interspecific interference behaviours by workers of the harvesting ant Messor capitatus (Hymenoptera Formicidae)," Ethology Ecology and Evolution, vol. 16, no. 3, pp. 197-207, 2004.

[49] B. Hölldobler, "Food robbing in ants, a form of interference competition," Oecologia, vol. 69, no. 1, pp. 12-15, 1986.

[50] L. LaPierre, H. Hespenheide, and A. Dejean, "Wasps robbing food from ants: a frequent behavior?" Naturwissenschaften, vol. 94, no. 12, pp. 997-1001, 2007.

[51] B. Corbara and A. Dejean, "Paper stealing on an arboricolous ant nest by the wasp Agelaia fulvofasciata degeer (Hymenoptera: Vespidae)," Sociobiology, vol. 39, no. 2, pp. 281-283, 2002.

[52] D. Naug, "Disease transmission and networks," in Encyclopedia of Animal Behavior, M. D. Breed and J. Moore, Eds., vol. 1, pp. 532-536, Academic Press, Oxford, UK, 2010. 

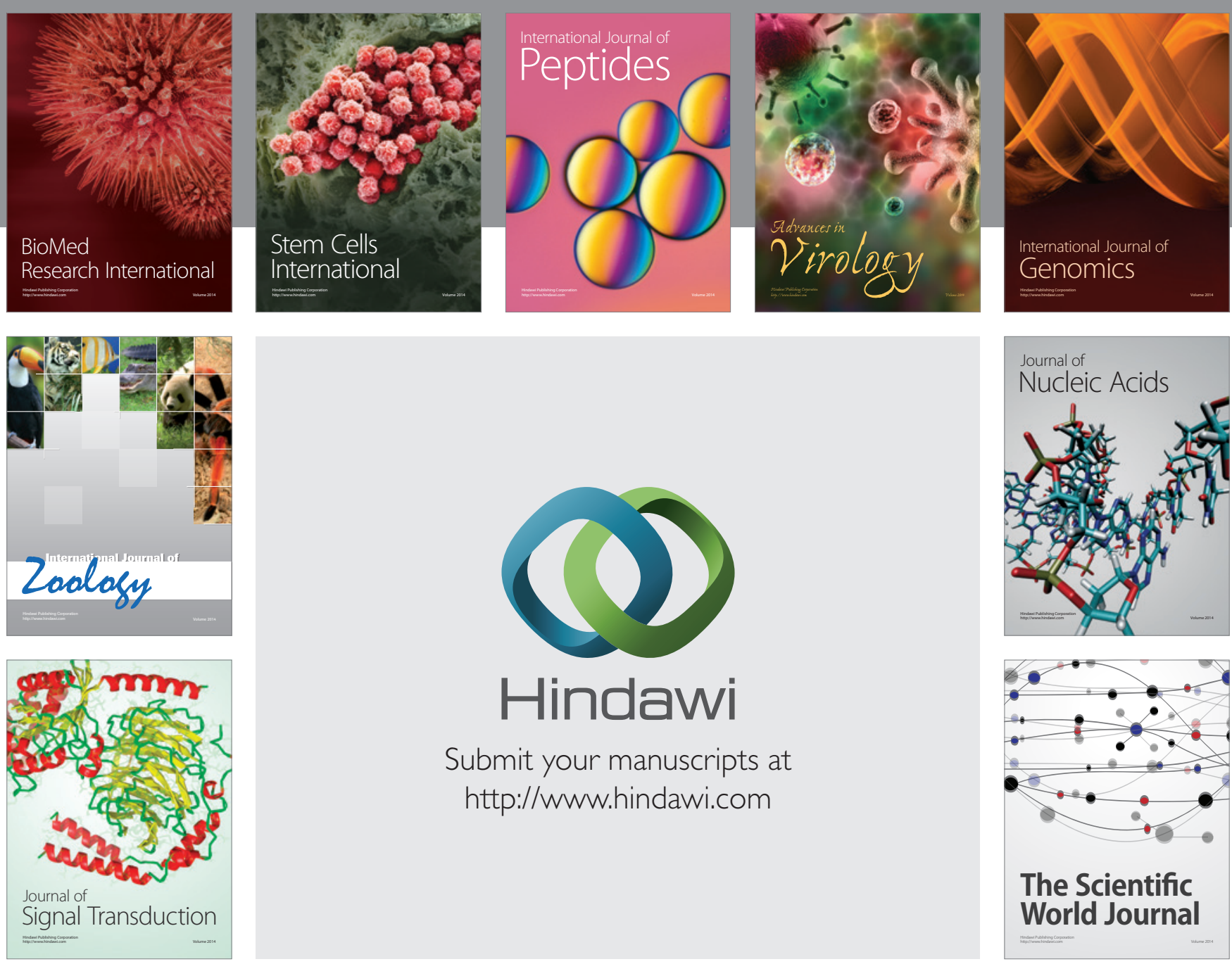

Submit your manuscripts at

http://www.hindawi.com
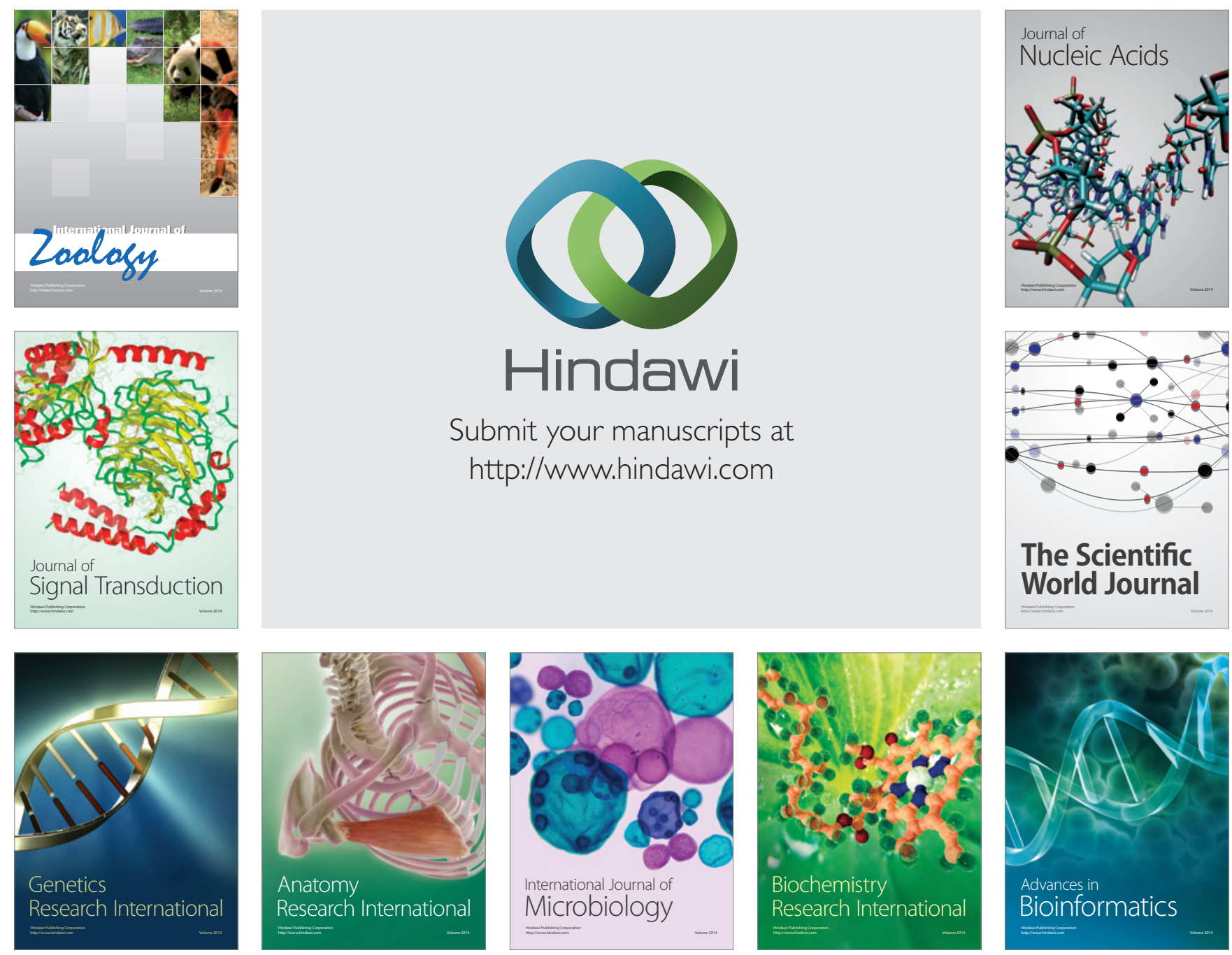

The Scientific World Journal
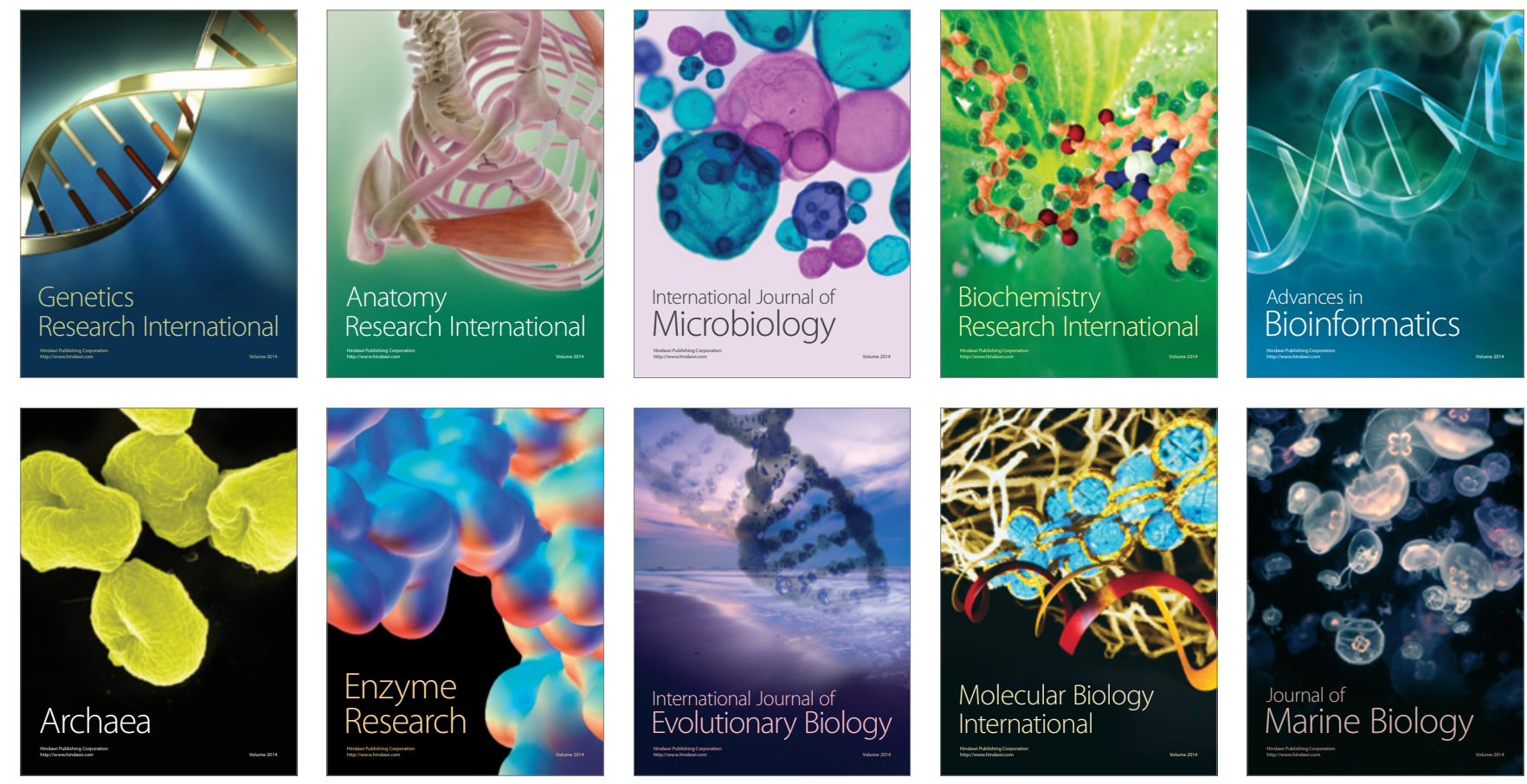